\title{
Manajemen Membangun Keluarga Sakinah Bagi Pasangan LDM (Long Distance Marriage)
}

\author{
Fashi Hatul Lisaniyah, Mira Shodiqoh, Yogi Sucipto \\ Institut Agama Islam Nahdlatul Ulama Tuban \\ E-mail: Lisaniyah1@gmail.com, mirashodiqoh@yahoo.com, \\ yogi.sucipto1999@gmail.com
}

\begin{abstract}
Abstrak: Menjadi Keluarga sakinah adalah dambaan setiap pasangan suami istri yang menjalani kehidupan rumah tangga. Hal tersebut juga tidak lepas dari keinginan pasangan yang menjalani hubungan jarak jauh atau disebut dengan Long Distance Marriage. Untuk mendapatkan keluarga sakinah memanglah tidak mudah. Dalam kehidupan rumah tangga harus bisa mengatur dan mengolah dengak baik, agar tercapai tujuan dari kebahagiaan rumah tangga tersebut. Maka diperlukan ilmu Manajemen keluarga sakinah yang harus dikuasai oleh setiap pasangan suami istri. Utamanya mereka yang menajalani hubungan jarak jauh. Penelitian ini merupakan penelitian studi kepustakaan, dimana dalam penyusunan artikel ini dari buku-buku dan literatur yang berhubungan dengan kajian yang dibahas. Maka metode yang disajikan adalah deskriptif analitis. Dengan hasil penelitiannya, Keluarga Sakinah merupakan keluarga yang memberikan ketentraman agar keinginan manusia dapat tercapai lahir dan batin, dimana manajemen berinteraksi antara suami istri perkawinan jarak jauh dengan mengikuti pola komunikasi antara lain: instrumen yang digunakan ketika berkomunikasi, inisiatif dalam berkomunikasi, kesan dan pesan yang dibangun di atas komunikasi, waktu dalam berkomunikasi, motif dalam berkomunikasi, efek setelah berkomunikasi. Selain itu harus memenuhi konsep keluarga sakinah sebagai berikut, memilih kriteria calon suami atau istri dengan tepat, dalam keluarga harus ada mawaddah dan rahmah mawaddah saling mengerti antara suami-istri saling menghargai, saling menerima, saling mempercayai, saling mempercayai, suami-istri harus menjalankan kewajibanya masing-masing, suami istri harus menghindari pertikaian, hubungan antara suami istri harus atas dasar saling membutuhkan, suami istri harus menjaga aqidah yang benar suami istri harus senantiasa menjaga makanan yang halal dan suami istri harus menjaga aqidah yang benar.

Kata Kunci: Manajemen, keluarga sakinah, Long Distance Marriage.
\end{abstract}




\section{Pendahuluan}

Manusia sebagai mahluk sosial, pada hakikatnya tidak bisa hidup sendirian. Manusia membutuhkan orang lain untuk memenuhi kebutuhannya melalui cara bersosialisasi. Perkawinan merupakan salah satu wujud manusia sebagai mahluk sosial. Perkawinan merupakan salah satu dari wujud manusia sebagai makhluk sosial. Perkawinan bertujuan menciptakan kehidupan keluarga antara suami istri dan anakanak serta orang tua agar tercapai suatu kehidupan yang aman dan tenteram (sakînah), pergaulan yang saling mencintai (mawaddah) dan saling menyantuni (rahmah). ${ }^{1}$

Menurut undang-undang RI nomor 1 tahun 1974 pengertian dan tujuan perkawinan terdapat dalam satu pasal, yaitu bab 1 pasal 1 menetapkan bahwa "perkawinan adalah ikatan lahir batin antara seorang pria dengan seorang wanita sebagai suami istri dengan tujuan membentuk rumah tangga, keluarga yang bahagia dan kekal berdasarkan Ketuhanan Yang Maha Esa". Dengan demikian jelas bahwa diantara tujuan perkawinan adalah membentuk sebuah rumah tangga yang sakinah, mawaddah dan warahmah.

Banyak manfaat penting perkawinan sebagai kebutuhan fitrah manusia, antar lain: 1) Pembentukan sebuah keluarga yang di dalamnya seseorang dapat menemukan kedamaian pikiran. Perkawinan merupakan perlindungan bagi seseorang yang merasa seolah-olah hilang di belantara kehidupan. Orang yang dapat menemukan pasangan hidup akan berbagi dalam kesenangan dan penderitaan. 2). Gairah seksual merupakan keinginan yang kuat dan menjadi hal yang penting. Setiap orang harus mempunyai pasangan untuk memenuhi kebutuhan seksualnya dalam lingkungan yang aman dan tenang. 3) Reproduksi sebagai wadah untuk melangsungkan keturunan. Anak-anak adalah produk hasil perkawinan yang sangat penting dalam memantapkan pondasi keluarga dan juga merupakan sumber kebahagiaan sejati bagi orang tua ${ }^{2}$.

Dalam Islam sendiri Manusia memang diciptakan sebagai mahluk yang berpasang - pasangan sesuai dengan Surat Ar Rum ayat 21. Allah SWT sendiri memerintahkan hamba-Nya untuk menikah. Itu karena menikah adalah ibadah dan memiliki manfaat atau hikmah. Salah satu

\footnotetext{
${ }^{1}$ Sajuti Thalib, Hukum Kekeluargaan Indonesia, (Jakarta: UI Press, 1974), hlm 47.

2 Ibrahim Amini, Bimbingan Islam untuk Kehidupan Suami-Istri, (Bandung: Al Bayan,1996), hlm 17 .
} 
hikmah menikah adalah akan mendapat bantuan dari Allah, karena orang tersebut menjaga kesucian dan menjauhi dosa. Dan secara tersirat Allah SWT menyampaikan kepada hamba-Nya untuk membina rumah tangga yang sakinah, mawadah, warahmah.

Dalam kehidupan perkawinan, setiap pasangan pasti mendampakan kehidupan yang harmonis, bahagia dan tentram. Namun seiring berjalannya kehidupan rumah tangga, untuk mewujudkan hal tersebut tidaklah mudah. Setiap pasangan akan mengalami berbagai rintangan ataupun masalah yang muncul, baik masalah, ekonomi, anak, perkerjaan, kesehatan, maupun dari salah satu pasangannya sendiri.

Seiring dengan perkembangan zaman. Tuntungan pekerjaan semakin berat, dan sedikitnya lapagan pekerjaan yang tersedia. Menjadikan persoalan baru dalam rumah tangga. Demi memenuhi kebutuhan hidup keluarganya, . Akibatnya banyak orang yang dituntut untuk bekerja di luar kota atau daerah karena tuntutan pekerjaan yang didapatkannya, sehingga banyak pasangan suami istri memutuskan untuk menjalin hubungan pernikahan jarak jauh dengan pasangan dan keluarganya. Pasangan suami istri yang menjalani keadaan ini, yang tidak bisa tinggal bersama dan terpisah jarak yang jauh bisanya disebut dengan Long Distance Marriage. ${ }^{3}$

Dari latar belakang tersebut, bahwa diperlukan manajemen untuk membangun keluarga sakinah untuk pasangan yang terpisah jarak atau tidak tinggal bersama (Long Distance Marriage) agar jarak tidak menjadikan suatu halangan atau rintangan pasti pasangan untuk menjadi keluarga yang tetap harmonis, dan sakinah.

\section{Metode Penelitian}

Dalam penyusunan artikel ini menggunakan jenis penelitian berupa studi kepustakaan di mana sumber artikel ini didapat dari buku-buku dan literatur yang berkaitan dengan kajian yang dibahas yakni manajemen membangun keluarga sakinah bagi pasangan yang menjalani LDM (Long Distance Marriage).

\section{Pengertian Keluarga Sakinah}

Menurut Dr Leha Zaleha Muhamat, perkataan 'keluarga' ialah komponen masyarakat yang terdiri daripada suami, istri dan anak-anak atau suami dan istri saja (sekiranya pasangan masih belum mempunyai anak baik anak kandung/angkat atau pasangan terus meredhai

\footnotetext{
${ }^{3}$ Ibrahim Amini, Bimbingan Islam untuk Kehidupan Suami-Istri, hlm 17.
} 
kehidupan dengan tanpa dihiasi dengan gelagat kehidupan anak-anak). Pengertian ini hampir sama dengan pengertian keluarga yang dijelaskan oleh Zakaria Lemat (2003: 71) yaitu, keluarga merupakan kelompok paling kecil dalam masyarakat, sekurang kurangnya dianggotai oleh suami dan istri atau ibu bapak dan anak-anak. Ia adalah asas pembentukan sebuah masyarakat. Kebahagiaan masyarakat adalah bergantung kepada setiap keluarga yang menganggotai masyarakat.

Sedangkan Arif mengatakan keluarga adalah unit kecil yang terdiri dari suami, istri, dan anak. Semua elemen yang tergabung dalah satu wadah yang memiliki tujuan yang sama yakni menciptakan keluarga yang harmonis atau keluarga sakinah. Keluarga sakinah merupakan. Keluarga sakinah merupakan keluarga yang utuh, damai, sejahtera, tenang dan tentunya merupakan suatu hal yang diidamkan oleh semua orang melakukan perkawinan. ${ }^{4}$ Dalam al-Qur'an pada surat Ar-Rūm ayat 21.4 yang artinya;

“Dan di antara tanda-tanda (kebesaran)-Nya ialah Dia menciptakan pasangan-pasangan untukmu dari jenismu sendiri, agar kamu cenderung merasa tenteram kepadanya. Dan Dia menjadikan di antaramu rasa kasih dan sayang. Sungguh, pada yang demikian itu benar-benar terdapat tanda-tanda kebesaran Allah bagi kaum yang berpikir."

Mahrus, Rofi'ah Dkk, dalam bukunya yang berjudul Fondasi Keluarga Sakinah Bacaan Mandiri Calon Pengantin mengungkapkan bahwa surat Ar -Rum ayat 21 terdapat istilah sakinah dalam keluarga atau rumah tangga dapat mengandung arti semua keadaan yang membuat keluarga itu tentram. Walaupun dalam realita kehidupan nyata dalam rumah tangga itu banyak ditemui rintangan, hambatan, maupun cobaan yang dihadapi oleh pasangan suami istri.

Kata سكينة memiliki makna ketenangan, merupakan jamak dari سكان berarti yang tenang, diam.6 Sedangkan menurut istilah sakinah berarti sebuah keluarga yang dapat menghadirkan ketentraman dan ketenangan bagi semua anggota keluarganya ${ }^{5}$.

Sofyan Basir mengutip dalam buku karya Dr. Hasan, Hj. Mohd Ali, bahwa Keluarga sakinah sering disebut sebagai keluarga yang bahagia.

\footnotetext{
4 A. Sugitanata, Manajemen Membangun Keluarga Sakinah yang Hidup Berbeda Kota Tempat Tinggal. MADDIKA: Journal of Islamic Family Law, 1(2), 1-10, 2020, hlm 3.

5 Sugitanata, hlm 3.
} 
Pandangan barat menyebutkan bahwa keluarga bahagia atau keluarga sejahtera ialah keluarga yang memiliki dan menikmati segala kemewahan material. Anggota-anggota keluarga tersebut memiliki kesehatan yang baik yang memungkinkan mereka menikmati limpahan kekayaan material. Bagi mencapai tujuan ini, seluruh perhatian, tenaga dan waktu ditumpukan kepada usaha merealisasikan kecapaian kemewahan kebendaan yang dianggap sebagai perkara pokok dan prasyarat kepada kesejahteraan.

Berdasarkan konsep sakinah dalam kitab qurrotul 'uyun dijelaskan bahwa, keluarga yang sakinah, mawaddah dan rahmah, itu adalah keluarga yang dapat menjalankan fungsinya dengan baik, yaitu;

a. fungsi religious

b. fungsi edukatif

c. fungsi protektif

d. fungsi ekonomi

e. fungsi reproduksi. ${ }^{6}$

Konsep keluarga sakinah dalam Islam sangat berbeda dengan konsep pandangan barat mengenahi rumah tanga yang bahagia. Menurut Dr. Hasan Hj. Mohd Ali (1993: 18 - 19) asas kepada kesejahteraan dan kebahagiaan keluarga di dalam Islam terletak kepada ketaqwaan kepada Allah SWT. Keluarga bahagia adalah keluarga yang mendapat keridhaan Allah SWT. Allah SWT ridha kepada mereka dan mereka ridha kepada Allah SWT. Firman Allah SWT: "Allah redha kepada mereka dan mereka redha kepada- Nya, yang demikian itu, bagi orang yang takut kepadaNya". (Surah Al-Baiyyinah : 8).

Jadi, dapat diseimpulkan bahwa keluarga sakinah ialah kondisi keluarga yang bahagia sesuai dengan keridhoan Allah, dan materi bukan sebagai tolak ukur kebahagiaan dalam rumah tangga.

\section{Karakteristik Keluarga Sakinah}

Berkaitan dengan kategori keluarga sakinah sendiri, satu orang dengan orang lainnnya memiliki pandangan yang berbeda.

Siti Chadijah ${ }^{7}$ mengungkapkan bahwa ada beberapa indikasi yang menghartarkan keluarga sakinah, menurut Abdullah Gymnastiar, antara

${ }^{6}$ F. Arina, Konsep Keluarga Sakinah Menurut Kitab Qurrah Al-'Uyun Karangan Syaikh Muhammad At-Tihami Bin Madani (Doctoral dissertation, IAIN PURWOKERTO). 2018.

7 S. Chadijah, Karakteristik Keluarga Sakinah dalam Islam. Rausyan Fikr: Jurnal Pemikiran Dan Pencerahan, 14(1). 2018. 
lain:

1. Pertama, menjadikan keluarga yang ahli sujud, keluarga yang ahli taat, keluarga yang menghiasi dirinya dengan dzikrullâh, dan keluarga yang selalu rindu untuk mengutuhkan kemuliaan hidup di dunia, terutama mengutuhkan kemuliaan di hadapan Allah swt. kelak di surga. Menjadikan tujuan utama keluarga berkumpul di surga dan sebagai amal ibadah.

2. Kedua, menjadikan rumah sebagai pusat ilmu. Memastikan setiap keluraga sungguh sungguh mencari ilmu. Anak - anak dibekali ilmu yang bermanfaat untuk dunia dan beroriantesi pada akhirat. Karena bekal harta habis, sedangkan ilmu akan bermanfaat selamanya.

3. Ketiga, jadikan rumah sebagai pusat nasihat. Menjadikan Keluarga yang bahagia itu keluarga yang dengan sadar bahwa kekayaanya saling menasehati, saling memperbaiki, serta saling mengkoreksi dalam kebenaran dan kesabaran. Setiap koreksian bahkan pujian yang diberikan oleh keluarga harus disyukuri. Hal ini karena mereka adalah bagian terdekat yang paling tahu apa yang dilakukan oleh anggota keluarga lainnya dalam kehidupan keseharian. Sehingga kritikan, koreksian, nasihat yang diberikan, dan bahkan pujian adalah lebih dekat pada keadaan diri yang sebenarnya.

4. Keempat, jadikan rumah sebagai pusat kemuliaan. Menjadikan keluarga Saling berlomba-lombalah dalam memunculkan kemuliaan. Berusaha keluarga itu sebagai contoh bagi keluarga yang lain. Beruntung jika sebuah keluarga dijadikan contoh teladan bagi keluarga yang lain. Itu artinya, setiap anggota keluarga akan berlomba untuk kebaikan dan mendapatkan pahala kebaikan.

Terdapat beberapa ciri-ciri keluarga sakinah, yang diungkapkan oleh Sofyan Bashir (2019) ${ }^{8}$ diantaranya :

a. Rumah Tangga Didirikan Berlandaskan Al-Quran Dan Sunnah: Landasan pembentukan keluarga sakinah adalah berpandukan AlQuran dan Sunnah. Iamenjadi panduan kepada suami istri sekiranya menghadapi berbagai masalah yang akan timbul dalam kehidupan berumahtangga. Dan tidak berlandaskan cinta semata.

b. Rumah Tangga Berasaskan Kasih Sayang (Mawaddah Warahmah): menanamkan dan memelihara kasih sayang sebagai wujud kehidupan

8 S. Basir, Membangun Keluarga Sakinah. Al-Irsyad Al-Nafs: Jurnal Bimbingan dan Penyuluhan Islam, 6(2). 2019. 
dalam menjalani rumah tangga. Kasih sayang sangat-sangat diperlukan kerana sifat kasih sayang yang wujud dalam sebuah rumah tangga dapat melahirkan sebuah masyarakat yang bahagia, saling menghormati, saling mempercayai dan tolong-menolong.

c. Mengetahui Peraturan Berumahtangga: membuat kesepakatan bersama yang tidak bertentangan dengan syari'at Agama. Dan dipatuhi oleh keduanya. Anak pula wajib taat kepada kedua orangtuanya selama perintah keduanya tidak bertentangan dengan larangan Allah. Lain pula peranan sebagai seorang suami. Suami merupakan ketua keluarga dan mempunyai tanggung jawab memastikan setiap ahli keluarganya untuk mematuhi peraturan dan memainkan peranan masing-masing dalam keluarga supaya sebuah keluarga sakinah dapat dibentuk.

d. Menghormati dan Mengasihi Kedua Ibu Bapak: Perkawinan bukanlah semata-mata menghubungkan antara kehidupan kedua pasangan tetapi ia juga melibatkan seluruh kehidupan keluarga kedua belah pihak, terutamanya hubungan terhadap ibu bapak kedua pasangan. Oleh itu, pasangan yang ingin membina sebuah keluarga sakinah seharusnya tidak menepikan ibu bapak dalam urusan pemilihan jodoh, terutamanya anak lelaki.

e. Menjaga Hubungan Kerabat dan Ipar: Antara tujuan ikatan perkawinan ialah untuk menyambung hubungan keluarga kedua belah pihak termasuk saudara ipar kedua belah pihak dan kerabatkerabatnya. Karena biasanya masalah seperti perceraian timbul disebabkan kerenggangan hubungan dengan kerabat dan ipar.

Nur Cholis Huda dalam karyanya yang berjudul "Mesra Sampai Akhir Hayat", menjelaskan beberapa hal yang ditempuh untuk menciptakan keluarga sakinah. Yaitu dengan menciptakan suasa rumah yang bahagia (baiti jannati) atau rumahku adalah surgaku. Dalam penjabaranya di sebut sebagai "Sembilan anak tangga menuju keluarga sakinah".

1. Senyum itu indah; biasakan lemah lembut didalam keluarga.

2. Kejutan kecil dan humor : hal seperti ini dapat menyenagkan keluarga, serta ungkapan lasih saying, dan humor dapat menjadi jendala yang menyegarkan.

3. Biasakan memberi bukan meminta : cinta dan kasih sayang tumbuh dalam suasa memberi, bukan meminta apalagi menuntut. Jika 
memberi kasih saying yang tulus, maka kita akan menerima kasih sayang.

4. Belajar menerima kenyataan.

5. Tunduk kepada agama.

6. Tetangga, tangga menuju ketentraman, menjaga hubungan baik dengan tetangga hal yang diperlukan dalam membangun keluarga sakinah.

7. Orang tua matahari kita, kewajiban berbakti kepada orang tua mereka selalu memberi tanpa meminta untuk kembali.

8. Uang, bahan bakar kehidupan. Dalam hadist dijelaskan bahwa "orang mukmin yang kuat lebih baik dan lebih dicintai Allah daripada orang mukmin yang lemah" maksudnya, kuat disini adalah kuat fisik, kuat mental, kuat iman, kuat sabar, istiqomah, dan yang paling penting adalah kuat hartanya.

9. Wilayah ranjang ibarat garam dan masakan. Kehidupan suami istri tanpa hubungan seks, ibarat masakan kehilangan rasa sedapnya karena kekurangan garam. Rasanya hambar. Tetapi garam bukan segala-galanya. ${ }^{9}$

\section{Long Distance Marriage (LDM)}

LDM adalah singkatan dari Long Distance Marriage atau hubungan jarak jauh pada perkawinan atau rumah tangga. Di mana dalam kasus ini suami dan istri tidak tinggal bersama, bisa beda kota, atau bahkan beda negara. Ica mengungkapkan bahwa Sarwono memberi pengertian bahwa long distance marriage adalah keadaan ketika pasangan suami istri dipisahkan oleh jarak karena suatu alasan yang menyebabkan pasangan sulit dan jarang untuk bertemu. Sedangkan Hampton menambahkan pengertian long distance marriage adalah dimana pasangan dipisahkan oleh jarak fisik yang tidak memungkinkan adanya kedekatan fisik untuk periode waktu tertentu. Bagi pasangan yang memilih untuk menjalani pernikahan long distance marriage banyak tantangan dan pengorbanan yang harus dilakukan karena kurangnya waktu bersama layaknya pasangan menikah yang tinggal satu rumah pada umumnya ${ }^{10}$.

Ica mengutip pernyataan Scott mendefenisikan pernikahan yang

9 Nur Cholis Huda, Mesra Sampai Akhir Hayat, Sembilan Langkah Membangun Keluarga Sakinah dengan Murah dan Mudah, ( Malang: Umm Press, 2014) Hlm. 35-175

10 I. Rahmayanti, Hubungan Penyesuaian Pernikahan Dengan Kepuasan Pernikahan Pada Istri Yang Menjalani Long Distance Marriage (Doctoral Dissertation, Universitas Islam Negeri Sultan Syarif Kasim Riau), 2018, hlm 11. 
menajalani hubungan jarak jauh adalah ditandai jarangnya pertemuan atau tatap muka antara suami istri dan biasanya pasangan tersebut tinggal di kota yang berbeda. Tidak hanya suami yang biasanya tinggal di luar kota untuk bekerja memenuhi kebutuhan hidup setelah menikah namun tidak jarang juga ditemui istri yang tinggal di luar kota berbeda dengan berbagai alasan seperti bekerja atau melanjutkan pendidikan yang lebih tinggi. Kemudian Berdasarkan hasil penelitian Hotl \& Stone) bahwa untuk mengkategorikan pasangan yang menjalani hubungan jarak 12 jauh maka digunakan faktor waktu dan jarak. Berdasarkan informasi demografis dari partisipan penelitian yang menjalani hubungan jarak jauh, didapat tiga kategori waktu terpisah (0, kurang dari 6 bulan, lebih dari 6 bulan), tiga kategori pertemuan (sekali seminggu, seminggu hingga sebulan, kurang dari satu bulan) dan tiga kategori jarak (0-1 mil, 2-294 mil, lebih dari 250 mil) ${ }^{11}$.

Berdasarkan pendapat ahli tersebut dapat disimpulkan bahwa long distance marriage merupakan perkawinan yang pasangan suami istri menjalani jarak jauh, dengan alasan baik bekerja, maupun pendidikan. sehingga tidak bisa berkontak fisik dalam waktu tertentu.

\section{Manajemen Keluarga Sakinah Pasangan LDM (Long Distance Marriage)}

Dalam keberlangsungan kehidupan dalam berumah tangga yang sakinah dan harmonis. Perlu adanya manajemen untuk membangun dan mempertahankan keutuhan keluarga, agar tetap sakinah dan harmonis. Manajemen sendiri, merupakan salah satu ilmu untuk mancapai suatu tujuan yang diinginkan. Dengan manajemen yang baik, akan memudahkan pasangan suami istri untuk melaksanakan amanah Allah SWT dalam mewujudkan keluarga sakinah.

Manajemen keluarga sakinah adalah ilmu dan seni mengatur, mengolah dan memanfaatkan unsur-unsur kehidupan sesuai dengan perintah dan larangan Allah SWT, sehingga terwujudlah insan yang beriman, cerdas dan bertaqwa kepada Allah SWT ${ }^{12}$. Dari pengertian tersebut, dapat kita simpulkan bahwa di dalam kehidupan rumah tangga juga diperlukan ilmu dan seni dalam mengatur dan memanfaatkan amanah Allah SWT. Seperti halnya pada suatu perusahaan, kalau

${ }^{11}$ I. Rahmayanti, Hubungan Penyesuaian Pernikahan Dengan Kepuasan Pernikahan Pada Istri Yang Menjalani Long Distance Marriage (Doctoral Dissertation, Universitas Islam Negeri Sultan Syarif Kasim Riau), 2018, hlm 11.

12 A. Sugitanata, Manajemen Membangun Keluarga Sakinah yang Hidup Berbeda Kota Tempat Tinggal. MADDIKA: Journal of Islamic Family Law, 1(2), 1-10, 2020, hlm 6. 
manajemennya jelek maka gagal dan hancurlah perusahaan tersebut, begitu juga pada menejemen dalam rumah tangga.

Manajemen dalam membangun keluarga sakinah khususnya bagi pasangan yang tinggalnya berjauhan, tidak tinggal bersama, atau istilahnya disebut Long Distance Marriage (LDM) tidaklah jauh berbeda dengan manajemen membangun keluarga sakinah bagi pasangan yang tinggal bersama. Hanya saja ada sedikit perbedaan yang perlu ditekankan, dan diperhatikan, yaitu dalam hal komunikasi. Komunikasi menjadi poin penting dan kunci utama bagi pasangan yang menjalani Long Distance Marriage (LDM) dalam membangun keluarga yang sakinah dan tetap harmonis walaupun hidup berbeda kota tempat tinggal, atau berjauhan.

Komunikasi merupakan kegiatan mahluk sosial, sebagai proses interaksi antar individu. Dalam proses komunikasi tidak selamanya berjalan dengan lancar dan baik, namun terdapat hambatan-hambatan yang mucul sehingga menimbulkan sebuah ketidakpahaman atau permasalahan. Beberapa pola komunikasi yang harus diterapkan agar komunikasi dengan antar pasangan suami istri tetap berjalan lancar dan baik ${ }^{13}$.

Intrumen Yang Dipakai Ketika Berkomunikasi; pada saat ini alat komunikasi seperti $\mathrm{Hp}$ adalah alat yang paling mudah dijumpai dan digunakan untuk berkomunikasi dengan pasangan dalam jarak jauh.

1. Inisiatif dalam komunikasi; saling inisiatif dalam memulai komunikasi terlebih dahulu, tidak perlu menunggu salah satu menghubungi terlebih dahulu.

2. Kesan dan pesan yang dibangun pada komunikasi; Kesan dan pesan komunikasi yang utama di bahas dalam interaksi pasangan suami istri yang menjalani hubungan jarak jauh (Long Distance Marriage) bisa dalam bentuk menanyakan keadaan, pekerjaan dan hingga masalahmasalah pribadi yang dialami oleh pasangan. Dengan komunikasi seperti itu akhirnya pasangan mampu mengobati rasa kerinduan dan saling memberikan dukungan atau penyemangat dalam suatu pekerjaan yang sangat membantu membangun hubungan pasangan yang menjalani Long Distance Marriage.

3. Waktu dalam berkomunikasi; Menyesuaikan waktu dengan masing masing pasangan dalam waktu berkomunikasi. Karena tiap pasangan

${ }^{13}$ E. Juairiyah, Pola Komunikasi Suami Istri Jarak Jauh. Jurnal Ilmiah. Ilmu Komunikasi Universitas Sebelas Maret.. Diakses tanggal 20 Desember. 2016. 
punya waktu senggang yang berbeda-beda. Dengan syarat komunikasi tetap dilakukan dengan rutin, agar rumah tangga tetap harmonis walau terpsah jarak yang jauh.

4. Motif dalam Komunikasi; Pertama, motif untuk mengetahui kabar atau keadaan pasangannya. Kedua, mengungkapkan perasaan kerinduan terhadap pasangan. Ketiga, tetap terjaga hubungan antar pasangan.

5. Efek setelah Berkomunikasi; muncul perasaan lega, karena telah bertukar pikiran, mengungkapkan perasaan antar pasangan. Dengan berkomunikasi, beban permasalahan tetap bisa dipecahkan.

6. Kewenangan dalam Komunikasi; yang dimaksud dengan kewenangan dalam komunikasi pasangan suami istri yang menjalani Long Distance Marriage berhubungan dengan keputusan tentang anak, baik dalam pengasuhan, pendidikan, pemenuhan dan pengaturan kebutuhan rumah tangga.

Selain menerapkan pola komunikasi di atas, pasangan suami istri yang menjalani kehidupan Long Distance Marriage harus mengatur atau mengolah sebuah keluarga agar menjadi keluarga sakinah. Beberapa cara membangun keluarga sakinah yang dijelaskan oleh Sofyan Bashir ${ }^{14}$ :

a) Memilih Kriteria Calon Suami atau Istri dengan Tepat, Agar terciptanya keluarga yang sakinah, maka dalam menentukan kriteria suami maupun istri haruslah tepat. Diantara kriteria tersebut misalnya beragama islam dan shaleh maupun shalehah; berasal dari keturunan yang baik-baik; berakhlak mulia, sopan santun dan bertutur kata yang baik. Dengan memilih calon pasangan yang tepat, akan memeberikan ketentraman hati jika memang terpaksa harus menjalani hubungan jarak jauh.

b) Dalam keluarga Harus Ada Mawaddah dan Rahmah. Mawaddah adalah jenis cinta membara, yang menggebu-gebu. sedangkan rahmah adalah jenis cinta yang lembut, siap berkorban dan siap melindungi kepada yang dicintai. Rasa damai dan tenteram hanya dicapai dengan saling mencintai. Maka rumah tangga muslim punya ciri khusus, yakni bersih lahir bathin, tenteram, damai dan penuh hiasan ibadah. Walaupun pasangan suami istri terpisah jarak, keduanya harus tetap menjaga rasa cinta diantara keduanya. Agar keluarga

14 S. Basir, Membangun Keluarga Sakinah. Al-Irsyad Al-Nafs: Jurnal Bimbingan dan Penyuluhan Islam, 6(2), 2019, hlm 101. 
tetap harmonis dan penuh cinta.

c) Saling Mengerti Antara Suami-Istri, Seorang suami atau istri harus tahu latar belakang pribadi masing-masing. Karena pengetahuan terhadap latar belakang pribadi masing-masing adalah sebagai dasar untuk menjalin komunikasi masing-masing. Dan dari sinilah seorang suami atau istri tidak akan memaksakan egonya. Disamping saling mengerti perbedaan, suami istri juga dituntut saling mengerti keadaan pasangan jika memang harus menjalani hubungan jarak jauh untuk waktu tertentu.

d) Saling Menerima, Suami istri harus saling menerima satu sama lain. Suami istri itu ibarat satu tubuh dua nyawa. Saling menerima kekurangan dan kelebihan masing - masing. Misal Baik dalam hal pekerjaan yang harus jauh terpisah dari suami, istri harus menerima dengan baik.

e) Saling Menghargai, Seorang suami atau istri hendaklah saling menghargai dalam hal Perkataan dan perasaan masing- masing, Bakat dan keinginan masing-masing, Menghargai keluarga masing-masing. Sikap saling menghargai adalah sebuah jembatan menuju terkaitnya perasaan suami-istri.

f) Saling Mempercayai, Dalam berumahtangga seorang istri harus percaya kepada suaminya, begitu pula dengan suami terhadap istrinya ketika ia sedang berada di luar rumah. Point ini Sangat penting bagi keluarga yang menjalani hubungan jarak jauh. Suami maupun istri harus menanamkan rasa saling percaya kepada pasangannya, karena jika tidak, hubungan jarak jauh tidak akan sukses dan berjalan lancar. Rumah tangga akan penuh kecurigaan antar pasangan.

g) Suami-Istri Harus Menjalankan Kewajibanya Masing-Masing, Suami mempunyai kewajiban mencari nafkah untuk menghidupi keluarganya, tetapi disamping itu ia juga berfungsi sebagai kepala rumah tangga atau pemimpin dalam rumah tangga. Menikah bukan hanya masalah mampu mencari uang, walaupun ini juga penting, tapi bukan salah satu yang terpenting. Istri mempunyai kewajiban taat kepada suaminya, mendidik anak dan menjaga kehormatannya. Walaupun terpisah jarak, tugas dan kewajiban masing - masing suami istri tetap harus dijalankan. Kecuali hal - hal yang memang tidak bisa dijangkau karena terpisah jarak. 
h) Suami Istri Harus Menghindari Pertikaian, Pertikaian adalah salah satu penyebab retaknya keharmonisan keluarga, bahkan apabila pertikaian tersebut terus berkesinambungan maka dapat menyebabkan perceraian. Suami istri utamanya yang menjalani hubungan jarak jauh harus selalu menetramkan hati pasangannya, meminimalisir hal- hal yang memicu pertikaian.

i) Hubungan Antara Suami Istri Harus Atas Dasar Saling Membutuhkan, Seperti pakaian dan yang memakainya (hunna libasun lakum wa antum libasun lahunna (Al-Qur'an surat Al-Baqarah ayat:187), peran saling membutuhkan harus tetap ada walau menjalanni hubungan jarak jauh, agar rasa saling ketergantungan dan membutuhkan antar pasangan.

j) Suami Istri Harus Senantiasa Menjaga Makanan yang Halal, Memberikan rizki yang halal adalah kewajiban bagi orangtua kepada anak dan suami kepada keluarganya.

k) Suami Istri Harus Menjaga Aqidah yang Benar, suami dan istri yang menjalani hubungan jarak jauh, harus teguh menjaga aqidah, agar terhindar dari godaan syetan untuk melakukan hal - hal yang tidak baik dan perkara yang merusak keutuhan rumah tangga.

Membina suatu keluarga yang bahagia memang tidaklah mudah, tapi dengan kesungguhan masing - masing pasangan untuk saling menerapkan konsep tersebut, rumah tangga akan menjadi keluarga sakinah.

\section{Penutup}

Pentingnya manajemen membangun keluarga sakinah bagi pasangan yang menjalani hubungan jarak jauh. Karena dengan ilmu manajemen kelauarga sakinah kita dapat seni mengatur, membina dan memanfaatkan unsur-unsur kehidupan sesuai dengan perintah dan larangan Allah SWT, sehingga orang yang beriman, berakal dan bertakwa kepada Allah SWT. Untuk dikatakan keluarga itu sakinah jika dalam kehidupan keluarga dapat terjalin komunikasi yang baik, saling percaya dan memahami antar pasangan. Perkawinan Jarak Jauh dapat mengikuti pola komunikasi antara lain: instrumen yang digunakan ketika berkomunikasi, inisiatif dalam berkomunikasi, kesan dan pesan yang dibangun di atas komunikasi, waktu dalam berkomunikasi, motif dalam berkomunikasi, efek setelah berkomunikasi. Selain itu harus memenuhi konsep keluarga sakinah sebagai berikut, memilih kriteria calon suami atau istri dengan 
tepat, dalam keluarga harus ada mawaddah dan rahmah mawaddah saling mengerti antara suami-istri saling menghargai, saling menerima, saling mempercayai, saling mempercayai, suami-istri harus menjalankan kewajibanya masing-masing, suami istri harus menghindari pertikaian, hubungan antara suami istri harus atas dasar saling membutuhkan, suami istri harus menjaga aqidah yang benar suami istri harus senantiasa menjaga makanan yang halal dan suami istri harus menjaga aqidah yang benar.

\section{Daftar Pustaka}

Abdullah Gymnastiar. Membangun Keluarga: 4 Visi Rumah Tangga sakinah Mawaddah wa rahmah. Bandung: MQS, Pustaka Grafika, 2002.

Ibrahim Amini. Bimbingan Islam untuk Kehidupan Suami-Istri. Bandung: Al Bayan, 1996.

Ilyas Kahar. Manajemen Strategi Keluarga Sakinah (Menuju Keluarga Bahagia). Bandung: Mandar Maju, 1996.

I. Rahmayanti. Hubungan Penyesuaian Pernikahan Dengan Kepuasan Pernikahan Pada Istri Yang Menjalani Long Distance Marriage (Doctoral Dissertation, Universitas Islam Negeri Sultan Syarif Kasim Riau), 2018. Nur Cholis Huda. Mesra Sampai Akhir Hayat, Sembilan Langkah Membangun Keluarga Sakinah dengan Murah dan Mudah. Malang: Umm Press, 2014.

Rofiah Machrus dkk. Fondasi Keluarga Sakinah Bacaan Mandiri Calon Pengantin. Jakarta: Subdit Bina Keluarga Sakinah, Direktorat bina KUA \& Keluarga Sakinah, Ditjen Bimas Islam Kemenag RI, 2017.

Sajuti Thalib. Hukum Kekeluargaan Indonesia. Jakarta: UI Press, 1974.

Quraish Shihab. Membumikan al-Qur'an: Fungsi dan Peran Wahyu dalam Kehidupan Masyarakat. Bandung: Mizan, 2020.

A. Sugitanata. Manajemen Membangun Keluarga Sakinah yang Hidup Berbeda Kota Tempat Tinggal. MADDIKA: Journal of Islamic Family Law, 1(2), 2020.

E. Juairiyah. Pola Komunikasi Suami Istri Jarak Jauh. Jurnal Ilmiah. Ilmu Komunikasi Universitas Sebelas Maret, 2014.

F. Arina. Konsep Keluarga Sakinah Menurut Kitab Qurrah Al-'Uyun Karangan Syaikh Muhammad At-Tihami Bin Madani, Doctoral dissertation, IAIN PURWOKERTO, 2018.

S. Basir. Membangun Keluarga Sakinah. Al-Irsyad Al-Nafs: Jurnal Bimbingan dan Penyuluhan Islam, 6(2), 2019.

S. Chadijah. Karakteristik Keluarga Sakinah dalam Islam. Rausyan Fikr: 
The Indonesian Journal of Islamic Law and Civil Law Vol. 2, No. 2, Oktober, 2021, ISSN. 2809 - 3402

Jurnal Pemikiran Dan Pencerahan, 14(1), 2018. 